\title{
Anions as triggers in controlled release protocols from mesoporous silica nanoparticles functionalized with macrocyclic copper(II) complexes
}

\author{
Sameh El Sayed ${ }^{\mathrm{a}, \mathrm{b}, \mathrm{c}, \mathrm{d}}$ Michele Milani, ${ }^{\mathrm{d}}$ Chiara Milanese, ${ }^{\mathrm{d}}$ Maurizio Licchelli, ${ }^{\mathrm{d}, *}$ Ramón Martínez-Máñez,,${ }^{\mathrm{a}, \mathrm{b}, \mathrm{c}, *}$ and \\ Félix Sancenón ${ }^{\mathrm{a}, \mathrm{b}, \mathrm{c}}$
}

\begin{abstract}
Three different mesoporous silica nano-sized materials (SC1, SC2 and SC3), loaded with $\left[\mathrm{Ru}(\text { bipy })_{3}\right]^{2+}$ dye and functionalized on the external surface with three macrocyclic copper(II) complexes $(\mathbf{C 1}, \mathbf{C 2}$ and $\mathbf{C 3})$, were synthesized and characterised. When SC1, SC2 and SC3 were suspended in water the entrapped $\left[\mathrm{Ru}(\text { bipy })_{3}\right]^{2+}$ dye was free to diffuse from inner pores to the solution. However, addition of anions induced certain degrees of pore blockage, with subsequent dye release inhibition. Small monovalent and divalent anions were unable to induce complete pore blockage, whereas bulky and highly charged anions induced marked
\end{abstract}

reductions in $\left[\mathrm{Ru}(\text { bipy })_{3}\right]^{2+}$ delivery. The best $\left[\mathrm{Ru}(\text { bipy })_{3}\right]^{2+}$ delivery inhibitors were ATP and hexametaphosphate anions. Inhibition was ascribed to the interaction of anions with the grafted $\mathrm{Cu}^{\mathrm{II}}$ complexes on the surface of the SC1, SC2 and SC3 supports. The hexametaphosphate anion was selected to prepare two capped materials (SC1-mPh and SC3-mPh). Studies of the $\left[\mathrm{Ru}(\text { bipy })_{3}\right]^{2+}$ dye release from solids SC1-mPh and SC3-mPh alone and in the presence of a collection of selected anions $\left(\mathrm{HS}^{-}, \mathrm{F}^{-}, \mathrm{Br}^{-}, \mathrm{Cl}^{-}, \mathrm{I}^{-}\right.$, $\mathrm{CN}^{-}, \mathrm{HPO}_{4}{ }^{2-}, \mathrm{AcO}^{-}$, citrate, $\mathrm{NO}_{3}{ }^{2-}, \mathrm{HCO}_{3}^{-}$, $\mathrm{SO}_{4}{ }^{2-}$ and $\mathrm{S}_{2} \mathrm{O}_{8}{ }^{2-}$ ), amino acids (alanine and histidine), thiol-containing biomolecules (cysteine, methylcysteine, homocysteine and GSH) and oxidants $\left(\mathrm{H}_{2} \mathrm{O}_{2}\right)$ were performed. None of the chemicals tested, except hydrogen sulphide, was able to induce remarkable cargo delivery in both solids. The observed dye release was ascribed to a demetallation reaction of the $\mathbf{C 1}$ and $\mathbf{C 3}$ complexes induced by the hydrogen sulphide anion.

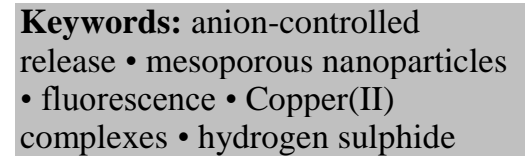

\section{Introduction}

The combination of supramolecular chemistry concepts with inorganic materials has recently led to the preparation of nanodispositives/nanomachines with features that are hardly achievable with single counterparts alone. ${ }^{[1]}$ These hybrid materials have found numerous applications in several scientific and technological fields. Among the realm of these smart materials, the concept of nanoscopic "gated materials" has gained special attention in recent years given their use for the controlled release of certain species upon the application of external stimuli. ${ }^{[2]}$ In general, these gated materials are constructed by the arrangement of two components: (i) an inorganic porous scaffold and (ii) certain organic molecules anchored to the external surface of the support. The

${ }^{a}$ Centro de Reconocimiento Molecular y Desarrollo Tecnológico (IDM), Unidad Mixta Universidad Politécnica de Valencia-Universidad de Valencia, Spain.

${ }^{b}$ Departamento de Química, Universidad Politécnica de Valencia, Camino de Vera s/n, 46022, Valencia, Spain.E-mail: rmaez@qim.upv.es

${ }^{c}$ CIBER de Bioingeniería, Biomateriales y Nanomedicina (CIBER-BBN).

${ }^{d}$ Dipartimento di Chimica, Università di Pavia, via Taramelli 12, I-27100 Pavia,

Italy.E-mail: maurizio.licchelli@unipv.it inorganic scaffold is used as a nanoscopic reservoir in which large amounts of different molecular cargoes (dyes, fluorophores, drugs, etc.) can be stored in inner pores. In addition, the (supra)molecular entities attached to the outer surface of the support are able to control cargo delivery through the change of their characteristics upon the application of external stimuli (e.g. light, $\mathrm{pH}$, temperature, magnetic fields, presence of certain (bio)chemical species, etc. $)^{[3]}$

These gated supports have found outstanding applications in controlled release protocols in biotechnological and biomedical fields, especially in the drug delivery area for the treatment of different diseases. ${ }^{[4]}$ In most cases mesoporous MCM-41-type solids have been selected to develop these gated materials because of their positive features, such as relatively well-known functionalization chemistry (using trialkoxysilane derivatives), stability and presence of controlled pore diameter within the nanometric range (typically $2-3 \mathrm{~nm}) .{ }^{[5]}$

Furthermore, in the last few years, gated materials have been successfully applied to develop new sensing protocols with enhanced recognition abilities. ${ }^{[6]}$ In this case too, hybrid materials are prepared using an inorganic porous support, with certain binding sites anchored to the external surface. The underlying idea of this approach is that the coordination or reaction of a certain analyte with binding units on the porous solid can modulate the transport of 
a previously stored dye from pores to the solution, giving rise to a chromo-fluorogenic signal. ${ }^{[7-9]}$ By means of this approach, gated sensory materials for the chromo-fluorogenic detection of cations, ${ }^{[10]}$ anions ${ }^{[11]}$ and neutral species ${ }^{[12]}$ have been recently described.

A special characteristic of gated materials, used for sensing or delivery purposes, is the appearance of synergistic features that arise from the combination of solid inorganic scaffolds and suitable functional groups. ${ }^{[13]}$ Surface functionalization is a key issue in these gated systems. Apart from designing systems capable of controlling the opening/closing of pores, it is also possible to include certain molecular obstacles at pore outlets that can modulate mass transport at the nanometric level. ${ }^{[14]}$ The use of functionalized mesoporous supports is a promising platform for designing more complex delivery smart systems, in which the events of guest loading, controlled release (by grafting gated ensembles) and modulation of delivery rates (by incorporating certain molecular entities that impose some impediment to cargo delivery) can be envisioned.

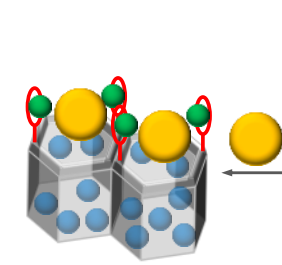

SC1-mPh, SC3-mPh
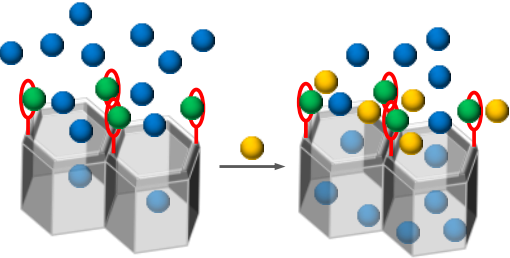

$\mathrm{sc} 1, \mathrm{sc2}, \mathrm{Sc} 3$
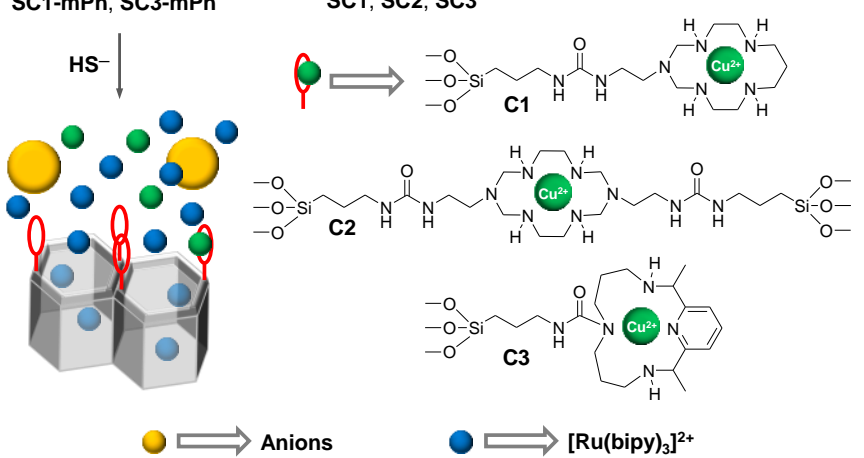

Scheme 1. Schematic representation of solids SC1, SC2 and SC3 functionalized with complexes $\mathbf{C 1}, \mathbf{C 2}$ and $\mathbf{C 3}$. Addition of anions of different sizes and charges induced different degrees of pore closure. The materials capped with hexametaphosphate anion (SC1-mPh and SC3-mPh) were selectively opened upon the addition of the hydrogen sulphide anion.

According to this background, there are numerous and different molecular, biomolecular, and supramolecular entities that have been attached to the external surface of silica mesoporous supports to prepare gated materials. ${ }^{[15]}$ In this context, very few reports have dealt with the use of metal complexes as gating functionalities. One of the first examples was described by Choi and co-workers in 2011. ${ }^{[16]}$ These authors prepared mesoporous silica nanoparticles loaded with curcumin and functionalized the external surface with a 18-crown- 6 derivative. Addition of $\mathrm{Cs}^{+}$cation induced pore closure due to the formation of sandwich complexes with the grafted macrocycle. However in the presence of $\mathrm{K}^{+}$, remarkable dye delivery was observed, which was attributed to the formation of $1: 1$ $\mathrm{K}^{+}$-macrocycle complexes and the subsequent displacement of the bulky $\mathrm{Cs}^{+}$cation. Following a similar approach, Leung and coworkers grafted three different dibenzocrown ethers onto the external surface of $\mathrm{Fe}_{3} \mathrm{O}_{4}$ nanoparticles coated with a mesoporous silica layer. ${ }^{[17]}$ The pores of nanoparticles were loaded with doxorubicin and capped upon the addition of $\mathrm{Na}^{+}$and $\mathrm{Cs}^{+}$cations. In this case, pores were opened upon ultrasound irradiation, which induced the rupture of cation-macrocycle interactions. Some of us prepared silica mesoporous nanoparticles loaded with $\mathrm{Ru}(\text { bipy })_{3}{ }^{2+}$ dye and functionalized on the external surface with $\mathrm{Zn}^{2+}-2,2$ 'dipicolylamine complexes. The release of the entrapped dye was finely tuned upon the addition of selected anions. ${ }^{[18]}$

Other transition metal complexes have also been used as caps to develop pH-triggered hybrid materials. Along these lines, Jung and co-workers prepared hollow silica mesoporous nanoparticles loaded with curcumin and capped by $\mathrm{Cu}^{2+}$-phenanthroline complexes. ${ }^{[19]}$ The pores of the material remained capped at a neutral $\mathrm{pH}$, but when $\mathrm{pH}$ was lowered, the entrapped dye was released due to the protonation of phenanthrolines, with the subsequent rupture of the $\mathrm{Cu}^{2+}$ complexes. In a similar way, Zink and co-workers prepared mesoporous silica nanoparticles loaded with Hoechst 3342 dye and functionalized the external surface with chelating iminodiacetate subunits. ${ }^{[20]}$ Pores were capped upon the addition of divalent metal cations $\left(\mathrm{Co}^{2+}, \mathrm{Ni}^{2+}\right.$ and $\left.\mathrm{Ca}^{2+}\right)$, which were able to form complexes with the iminodiacetate moieties. The entrapped cargo was released when $\mathrm{pH}$ was lowered or in the presence of $2,2^{2}$-bipyridyne. In another similar work, chelating subunit $\mathrm{N}$-(3trimethoxysilylpropyl)ethylenediamine triacetate was anchored to the external surface of $\mathrm{Ru}$ (bipy) ${ }_{3}{ }^{2+}$-loaded mesoporous silica nanoparticles. ${ }^{[21]}$ Addition of $\mathrm{Cu}^{2+}$ or $\mathrm{Ni}^{2+}$ cations induced pore closing due to the formation of strong complexes with the grafted chelating units. Once again, the rupture of the anchored complexes at an acidic $\mathrm{pH}$ induced the release of the entrapped dye. Coordination polymers, formed between the $\mathrm{Zn}^{2+}$ cation and 1,4bis(imidazol-1-ylmethyl) benzene, have also been recently used to develop pH-triggered capped materials. ${ }^{[22]}$

However, all these studies missed one important characteristic of metal complexes: their potential use as receptors for anions. ${ }^{[23]}$ In fact, many studies have been conducted in solution and have demonstrated that metal complexes are able to form complexes with a large number of anions via either hydrogen bonding interactions, coordination to the metal centre or electrostatic attractive forces. ${ }^{[24]}$ Yet as far as we know, studies on the interactions of metal complexes with anions in relation to the modulation of mass transport in gated materials are rare. ${ }^{[18]}$ Nevertheless, these studies may be important to gain a better understanding of the role played by anions in gated ensembles and the interactions that negatively charged species and complexes display on functionalized surfaces.

Bearing these ideas in mind, we report here the synthesis and characterisation of three silica mesoporous materials (SC1, SC2 and SC3) loaded with a selected dye (i.e. $\mathrm{Ru}(\text { bipy })_{3}{ }^{2+}$ ) and functionalized on the outer surface with three different macrocyclic copper(II) complexes (C1, C2 and $\mathbf{C 3}$, respectively). A study of dye release in the presence of different anions is reported. A differential cargo delivery response was expected to occur in accordance with both the complex attached to the surface and the anion present in solution. Moreover, two materials capped with hexametaphosphate were also prepared and studies on $\mathrm{Ru}(\text { bipy })_{3}{ }^{2+}$ release in the presence of a collection of different anions, amino acids, thiolcontaining biomolecules and oxidants were carried out. A selective cargo delivery was observed in the presence of hydrogen sulphide. 

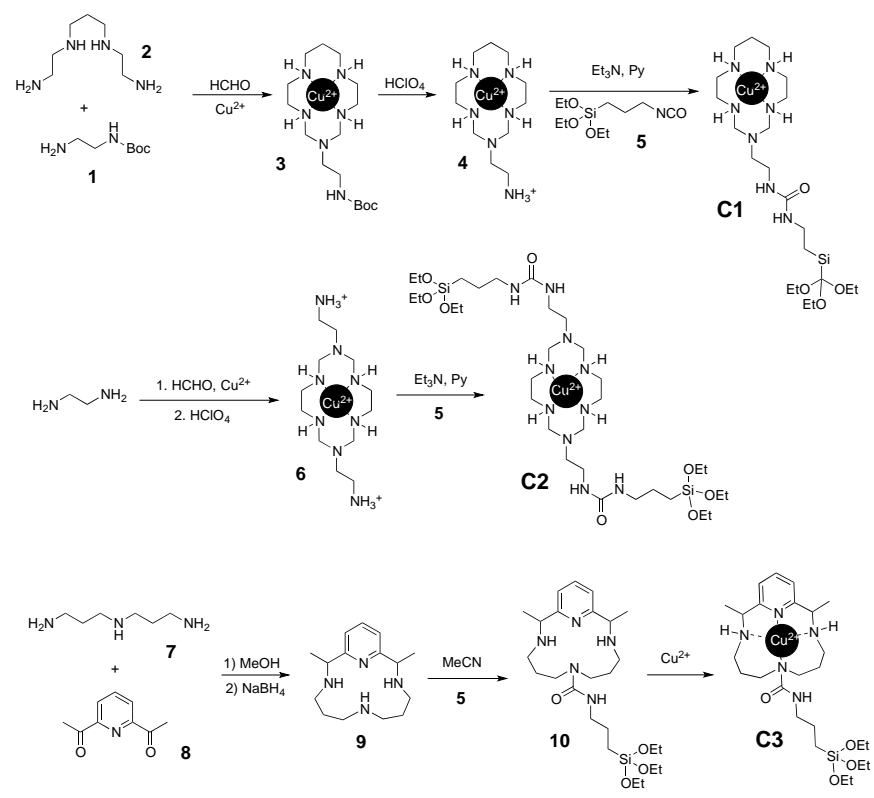

Scheme 2. Synthetic routes used for the preparation of complexes C1, C2 and $\mathbf{C 3}$.

\section{Results and Discussion}

Synthesis and characterizations of the solid materials: The nanosized hybrid materials SC1, SC2, and SC3 were obtained by properly combining a mesoporous silica as inorganic scaffold and three different macrocyclic copper(II) complexes. MCM-41 was selected as inorganic scaffold due to its suitable characteristics such as inertness, high homogeneous porosity, high load capacity and easy surface functionalization. Polyaza-macrocyclic complexes were chosen to functionalize the silica surface owing to their unique features: ${ }^{[25,26]}$ (i) high thermodynamic stability; (ii) kinetic inertness toward demetallation; (iii) interaction at the axial position(s) with additional ligand(s) (e.g. coordinating anions).

Mesoporous silica nanoparticles were synthesized in alkaline media following well-known procedures that make use of the cationic surfactant $n$-cetyltrimethylammonium bromide (CTAB) as directing agent for condensation of the inorganic precursor tetraethylorthosilicate (TEOS). ${ }^{[27]}$ The obtained powder was washed and the surfactant was subsequently removed by calcination. Then, the pores of the obtained nanoparticles were loaded with $\left[\mathrm{Ru}(\text { bipy })_{3}\right]^{2+}$ (solid So), followed by grafting of the complexes $\mathbf{C 1}$, $\mathbf{C 2}$ or $\mathbf{C 3}$ on the external surface. By this procedure the final solids SC1 (functionalized with C1), SC2 (with C2) and SC3 (using C3) were prepared (see Scheme 1). This synthetic protocol guarantees that $\mathbf{C 1}, \mathbf{C 2}$ and $\mathbf{C 3}$ complexes are preferentially anchored to the outer surface rather than inside the pore walls, which were filled with the bulky $\left[\mathrm{Ru}(\text { bipy) })_{3}\right]^{2+}$ dye. Moreover, the high stability (both kinetic and thermodynamic) of macrocyclic copper(II) complexes guarantees that metal ions are firmly held on the surface of silica nanoparticles even after dispersion in aqueous solution and in the presence of strongly coordinating species.

The synthetic procedure and the structures of complexes C1, $\mathbf{C 2}$ and $\mathbf{C 3}$ are depicted in Scheme 2. Complex $\mathbf{C 1}$ and $\mathbf{C 2}$ were prepared by template reactions ${ }^{[26,28]}$ driven by $\mathrm{Cu}^{\text {II }}$ ions. In the synthesis of C1, mono-Boc-protected ethylenediamine (1) was reacted with $N, N^{\prime}$-bis(2-aminoethyl)-1,3-propanediamine (2) and formaldehyde in the presence of $\mathrm{Cu}(\mathrm{OAc})_{2}$ in boiling methanol yielding aza-cyclam ${ }^{[26]}$ derivative $\mathbf{3}$, which was not isolated. Further deprotection of $\mathbf{3}$ with perchloric acid yielded $\mathbf{4}$ that was further reacted with (3-isocyanatopropyl)triethoxysilane (5) obtaining the final functionalized macrocyclic complex. A closely related procedure was used for the preparation of $\mathbf{C 2}$ complex. In this case a mixture of ethylenediamine, formaldehyde and $\mathrm{Cu}(\mathrm{OAc})_{2}$ were heated in methanol yielding di-aza-cyclam ${ }^{[24 c, 29]}$ complex $\mathbf{6}$. Further reaction of $\mathbf{6}$ with $\mathbf{5}$ afforded complex C2. Finally, complex $\mathbf{C 3}$ was obtained following an untemplated synthetic sequence. A condensation reaction between 3,3'-iminobis(propylamine) (7) and 2,6-diacetylpyridine (8), followed by a reduction of the formed imine bonds using sodium borohydride, resulted in macrocycle $\mathbf{9}$. In a second step, $\mathbf{9}$ was reacted with $\mathbf{5}$ to yield macrocycle 10, which was transformed into complex $\mathbf{C 3}$ by refluxing with $\mathrm{Cu}\left(\mathrm{ClO}_{4}\right)_{2}$ in acetonitrile. All new complexes were characterised by HRMS and UV-Vis, while organic intermediate were characterized by ${ }^{1} \mathrm{H}-\mathrm{NMR}$, ${ }^{13} \mathrm{C}-\mathrm{NMR}$, and by HRMS (see the Experimental Section).

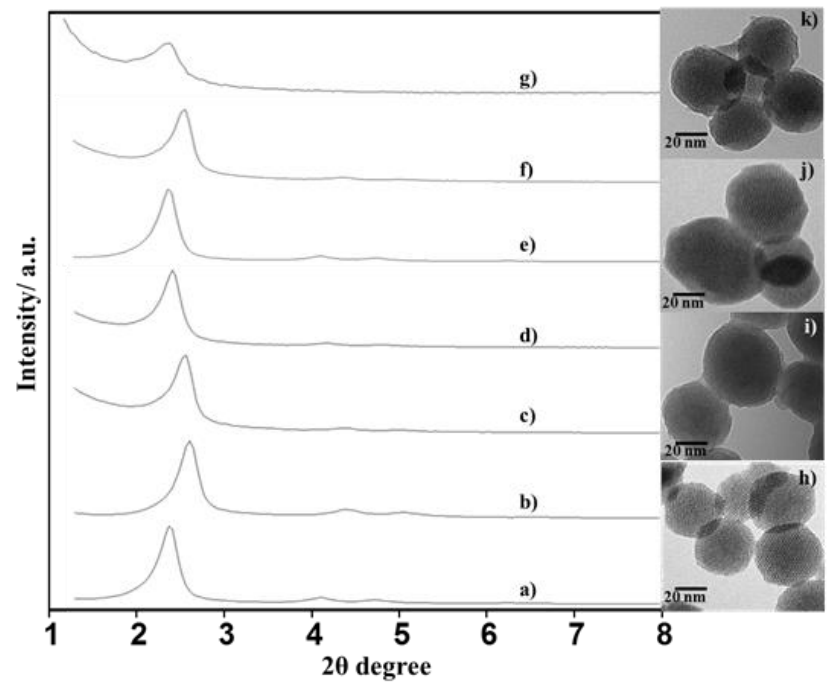

Figure 1. Left: powder X-ray patterns of the solids (a) MCM-41 as synthesised, (b) calcinated MCM-41, (c) SC1, (d) SC2, (e) SC3, (f) SC1mPh and (g) SC3-mPh. Right: TEM images of (h) the calcinated MCM-41 sample, (i) SC1, (j) SC3 and (k) SC3-mPh, showing the typical porosity of the MCM-41 mesoporous matrix.

MCM-41 nanoparticles and solids SC1, SC2 and SC3 were characterised using powder X-ray diffraction (PXRD), transmission electron microscopy (TEM), $\mathrm{N}_{2}$ adsorption-desorption isotherms, thermogravimetric measurements and elemental analyses. Figure 1 shows the PXRD patterns of MCM-41 as synthesised (1a), calcined MCM-41 (1b), SC1 (1c), SC2 (1d) and SC3 (1e) solids. PXRD of MCM-41 nanoparticles as-synthesised showed four low-angle peaks, typical of a hexagonal-ordered pore array that can be indexed as (100), (110), (200) and (210) Bragg reflections. A shift of the (100) peak and a remarkable broadening of the (110) and (200) in calcined MCM-41 were observed and ascribed to further condensation of silanols during the calcination step. ${ }^{[9 c]}$ The presence of the characteristic (100) reflection in the diffraction spectra obtained for solids SC1, SC2, and SC3 indicated that the mesoporous structure was preserved throughout the filling process with the dye and the anchoring of complexes C1, C2 and C3. Moreover, Figure 1 shows the TEM images of the micrometric MCM-41 solid support (1h) and final nanoparticles SC1 (1i), and SC3 $(1 \mathrm{j})$. As we can see in these images, the typical porosity associated with this type of inorganic support was present in all 
cases. The TEM images also show that the final solids were obtained as nanoparticles with diameters of ca. $100 \mathrm{~nm}$.

The $\mathrm{N}_{2}$ adsorption-desorption studies of calcined MCM-41, and of nanoparticles SC1, SC2, and SC3 were also carried out. The results are shown in Figure 2. Calcined MCM-41 showed a typical curve for this mesoporous support, which consisted in an adsorption step at an intermediate $P / P_{0}$ value $(0.1-0.3)$. This isotherm could be classified as type IV, characteristic of mesoporous materials, in which the observed step dealt with nitrogen condensation inside mesopores. The pore diameter distributions (PSD) of this sample were calculated by the Barret-Joyner-Halenda (BJH) method. ${ }^{[30]}$ The narrow $\mathrm{BJH}$ pore distribution and the absence of a hysteresis loop in this interval suggested the existence of uniform cylindrical mesopores (pore diameter of $2.58 \mathrm{~nm}$ and pore volume of $0.85 \mathrm{~cm}^{3}$ $\mathrm{g}^{-1}$, calculated on the adsorption branch of the isotherm). The pore diameter estimated by analysing the corresponding TEM images agreed with this value. The application of the Brunauer-EmmettTeller (BET) model ${ }^{[31]}$ gave a value of $1027 \mathrm{~m}^{2} \mathrm{~g}^{-1}$ for the total specific surface. According to PXRD, porosimetry and the TEM studies, an $a_{0}$ cell parameter of $3.57 \mathrm{~nm}$ and a wall thickness of 0.93 $\mathrm{nm}$ were calculated.

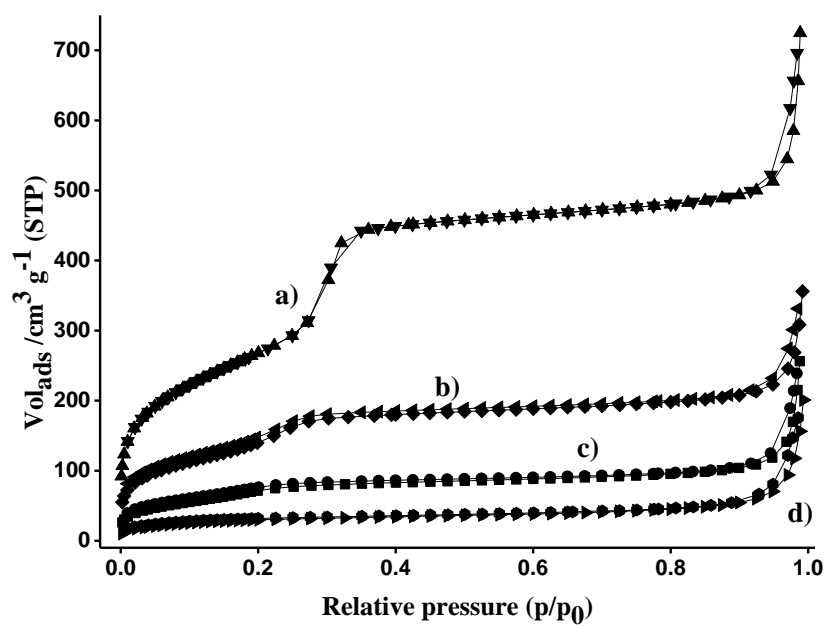

Figure 2. Nitrogen adsorption-desorption isotherms of (a) calcined MCM-41 mesoporous material, (b) SC3, (c) SC2 and (d) SC1.

Table 1. BET-specific surface values, pore volumes, and pore diameters calculated from the $\mathrm{N}_{2}$ adsorption-desorption isotherms.

\begin{tabular}{cccc} 
Solid & $\begin{array}{c}\text { S } \\
{\left[\mathrm{m}^{2} \mathrm{~g}^{-1}\right]}\end{array}$ & $\begin{array}{c}\text { BJH Pore } \\
\text { diameter }\end{array}$ & $\begin{array}{c}\text { Total } \\
{[\mathrm{nm}]}\end{array}$ \\
\hline MCM-41 & 1027 & 2.58 & 0.85 \\
SC1 & 111.6 & - & 024 \\
SC2 & 235.8 & - & 021 \\
SC3 & 311.2 & - & 0.28 \\
SC1-mPh & 302.6 & - & 020 \\
SC3-mPh & 268.5 & - & 0.18 \\
\hline b] Pore volumes & and & \\
\hline
\end{tabular}

[a,b] Pore volumes and pore diameters were associated with only intraparticle mesopores.

[a] Pore diameter was estimated by the BJH model, applied to the adsorption branch of the isotherm.

[c] Pore diameter values for SC1, SC2, SC3, SC1-mPh and SC3-mPh solids cannot be determined due to both loading of the pores with $\left[\mathrm{Ru}(\mathrm{bipy})_{3}\right]^{2+}$ dye and functionalization of the external surface with the corresponding complexes.

The $\mathrm{N}_{2}$ adsorption-desorption isotherms of solids SC1, SC2 and SC3 are typical of mesoporous systems with partially filled mesopores, and a remarkable decrease in both the adsorbed $\mathrm{N}_{2}$ volume and the specific surface area (see Table 1) was clearly observed. This reduction in the BET surface, compared with that of the MCM-41 starting material, was attributed to the loading of pores with the $\left[\mathrm{Ru}(\text { bipy })_{3}\right]^{2+}$ dye, and also to the functionalization of the surface with the macrocyclic $\mathbf{C 1}, \mathbf{C 2}$ and $\mathbf{C 3}$ complexes. Due to the same reasons (loading of the pores and functionalization of the external surface), pore diameter values for hybrid materials cannot be determined.

Finally, the content of organic material (both dye and macrocyclic complexes) in the final SC1, SC2 and SC3 nanoparticles was determined by thermogravimetric and elemental analyses. Results are summarized in Table 2.

Table 2. Contents of dye, complexes, and methaphosphate in the final nanoparticles (calculated by elemental and thermogravimetric analyses).

\begin{tabular}{cccc} 
Solid & $\begin{array}{c}\alpha_{\text {dye }}\left[\mathrm{mmol} \mathrm{g}^{-1}\right. \\
\left.\mathrm{SiO}_{2}\right]\end{array}$ & $\begin{array}{c}\alpha_{\text {complex }}\left[\mathrm{mmol} \mathrm{g}^{-1}\right. \\
\left.\mathrm{SiO}_{2}\right]\end{array}$ & $\begin{array}{c}\alpha_{\mathrm{mPh}}\left[\mathrm{mmol} \mathrm{g}^{-1}\right. \\
\left.\mathrm{SiO}_{2}\right]\end{array}$ \\
\hline $\mathbf{S C 1}$ & 0.29 & 0.103 & - \\
$\mathbf{S C 2}$ & 0.25 & 0.111 & - \\
$\mathbf{S C 3}$ & 0.39 & 0.107 & - \\
$\mathbf{S C 1}-\mathbf{m P h}$ & 0.36 & 0.103 & 0.03 \\
$\mathbf{S C 3}-\mathbf{m P h}$ & 0.38 & 0.107 & 0.04 \\
\hline
\end{tabular}

The differences observed in the content of ruthenium(II) complex $\left(\alpha_{\text {dye }}\right.$ in Table 2$)$ for materials SC1-SC3 can be ascribed to a partial loss of dye during functionalization reactions. Although reactions of loaded silica nanoparticles with copper(II) complexes C1-C3 were performed in the presence of free $\left[\mathrm{Ru}(\mathrm{bipy})_{3}\right]^{2+}$ (see Experimental Section) in order to reduce uncontrolled dye release during this process, it cannot be completely prevented. As a consequence, the final dye loadings could be affected to different extents depending the specific experimental conditions of functionalization reactions. Moreover, silanolate groups, which could form on the silica surface when it is functionalised with positively charged groups, ${ }^{[32]}$ might also influence the dye loading, as they contribute to balance the positive charge of metal ions beside the complex counterions $\left(\mathrm{Cl}^{-}\right.$ and $\mathrm{ClO}_{4}^{-}$for $\mathrm{Ru}^{\mathrm{II}}$ and $\mathrm{Cu}^{\mathrm{II}}$, respectively) and modulate the affinity toward the dye.

Dye release studies in the presence of anions and amino acids: Solids SC1, SC2 and SC3 were prepared by attaching complexes $\mathbf{C 1}, \mathbf{C 2}$ and $\mathbf{C 3}$ to the outer surface of the $\left[\mathrm{Ru}(\text { bipy })_{3}\right]^{2+}$-loaded MCM-41 nanoparticles. It is well established that $\mathrm{Cu}^{2+}$ complexes of linear and cyclic polyamines can bind anions and a number of good examples of $\mathrm{Cu}^{2+}$-polyamine complexes as anion receptors has been described. ${ }^{[33]}$ These studies have demonstrated that linear or cyclic polyamines that contain coordinatively unsaturated $\mathrm{Cu}^{2+}$ centres may establish strong and selective interactions with anions via coordination to the metal centre or through electrostatic interactions. Urea groups on the side-chains of complexes C1, C2 and C3 may eontribute to anion binding process by establishing H-bond interactions with anionic species, as recently reported for macrocyclic copper(II) complexes whose structures are closely related to $\mathbf{C 1}$ and $\mathbf{C 2}$. $^{[24 \mathrm{c}]}$

After taking into account the above mentioned facts, in a first step, the cargo release performance of nanoparticles SC1, SC2 and SC3 alone, and in the presence of selected anions (chloride, hydrogencarbonate, acetate, suberate, citrate, hydrogenphosphate, 
pyrophosphate, hexametaphosphate, AMP, ADP, and ATP) or amino acids (glycine, histidine, and lysine) was studied. In a typical experiment, $1 \mathrm{mg}$ of nanoparticles was suspended in $2 \mathrm{~mL}$ of water at pH 7.0 (10 mM HEPES buffer) in the absence and presence of the target anions or amino acids $\left(1.0 \times 10^{-4} \mathrm{M}\right)$ at room temperature. In both cases, fractions were taken from the suspensions of the solids and centrifuged to remove the solid. In these experiments a long delivery time $(15 \mathrm{~h})$ was selected in order to obtain the value of the maximum release of the $\left[\mathrm{Ru}(\mathrm{bipy})_{3}\right]^{2+}$ complex from pore voids. Dye delivery to the bulk solution was easily detected by monitoring the emission band of the $\left[\mathrm{Ru}(\mathrm{bipy})_{3}\right]^{2+}$ complex $\left(\lambda_{\mathrm{em}}=610 \mathrm{~nm}, \lambda_{\mathrm{ex}}=\right.$ $451 \mathrm{~nm}) .{ }^{[34]}$

Different papers report that MCM-41 may undergo structural modifications and partial dissolution when exposed to aqueous solutions under biologically relevant conditions (e.g. in phosphate buffer) ${ }^{[35]}$ Nevertheless, this instability has not been observed during the experiments performed in the presence of different anions (including phosphates) in the current work as well as in our previous studies concerning the use of other hybrid materials based on mesoporous silica scaffolds.

Figure 3 shows the release achieved for solid SC1 in the absence and presence of selected anions and amino acids. In the absence of any chemical species, the $\left[\mathrm{Ru}(\text { bipy })_{3}\right]^{2+}$ complex was free to diffuse from the inner of the pores to the bulk solution. This indicates that the $\mathbf{C 1}$ complexes, grafted onto the outer surface of nanoparticles, were unable to retain the cargo in pores. Upon the addition of amino acids (glycine, histidine and lysine), a significant $\left[\mathrm{Ru}(\mathrm{bipy})_{3}\right]^{2+}$ complex release was still observed. The same behaviour occurred in the presence of small anions (chloride, hydrogencarbonate, hydrogenphosphate, acetate) and suberate.

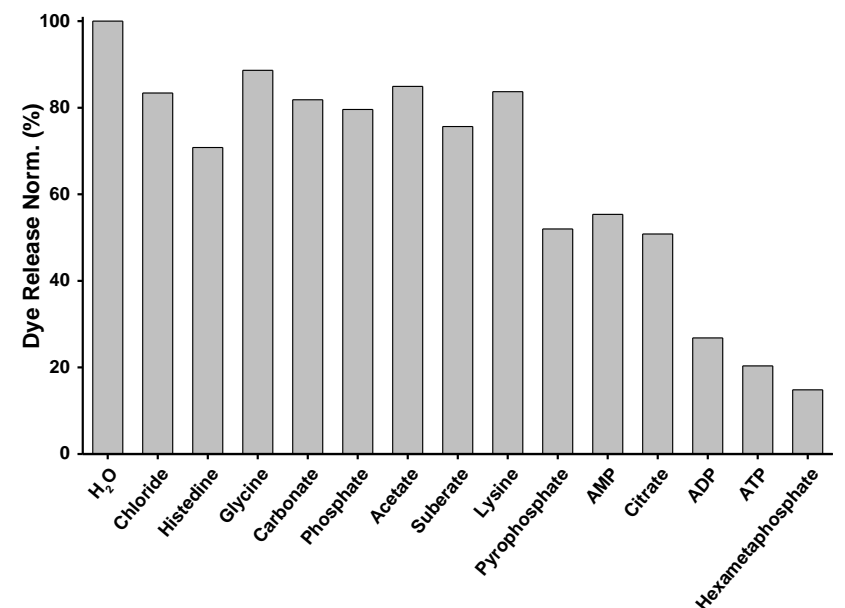

Figure 3. Release profiles of the $\left[\mathrm{Ru}(\text { bipy })_{3}\right]^{2+}$ complex from solid SC1 in water at $\mathrm{pH} 7.0$ alone and in the presence of selected anions and amino acids $\left(1.0 \times 10^{-4} \mathrm{M}\right)$ after $15 \mathrm{~h}$.

In contrast, a larger inhibition of cargo release was observed in the presence of pyrophosphate, citrate, hexametaphosphate and nucleotides (see Figure 3), which suggests that these anions coordinate to a greater extent the grafted $\mathrm{Cu}^{\mathrm{II}}$ complex. The order observed for the $\left[\mathrm{Ru}(\mathrm{bipy})_{3}\right]^{2+}$ release inhibition was: hexametaphosphate > ATP > ADP > AMP $\approx$ citrate $\approx$ pyrophosphate. A first look at these data suggests that cargo delivery inhibition could be mainly related with charge and size of anions. In fact, pyrophosphate (average charge: -2.72 at a neutral $\mathrm{pH}$ ) and citrate (with three negative charges) were able to induce similar pore closure as AMP, which is less charged (average charge:
-1.70 at $\mathrm{pH}$ 7.0) but bulkier than pyrophosphate and citrate. Moreover, when ADP was present in a suspension of solid SC1, a lower $\left[\mathrm{Ru}(\text { bipy })_{3}\right]^{2+}$ release was observed compared to that obtained in the presence of AMP, citrate and pyrophosphate. This greater inhibition can be ascribed to the increased charge of ADP (-2.72 at a neutral $\mathrm{pH}$ ), as well as to its bigger size. ATP, which has an average charge of -3.7 at a neutral $\mathrm{pH}$ and is bulkier than AMP and ADP, induces a stronger dye release inhibition (only $20 \%$ of the cargo was delivered after $15 \mathrm{~h}$ ). However, the most pronounced pore closure was observed in the presence of the hexametaphosphate anion, which has six negative charges. This cyclic polyphosphate induced tight pore closure as only ca. $15 \%$ of the cargo release was found after $15 \mathrm{~h}$. This high degree of inhibition can be ascribed to the strong interactions between hexametaphosphate anion and C1 grafted onto the external surface of nanoparticles, which occur due to the best combination of (i) anion affinity towards metal ions, (ii) high charge at neutral $\mathrm{pH}$, and (iii) large size.

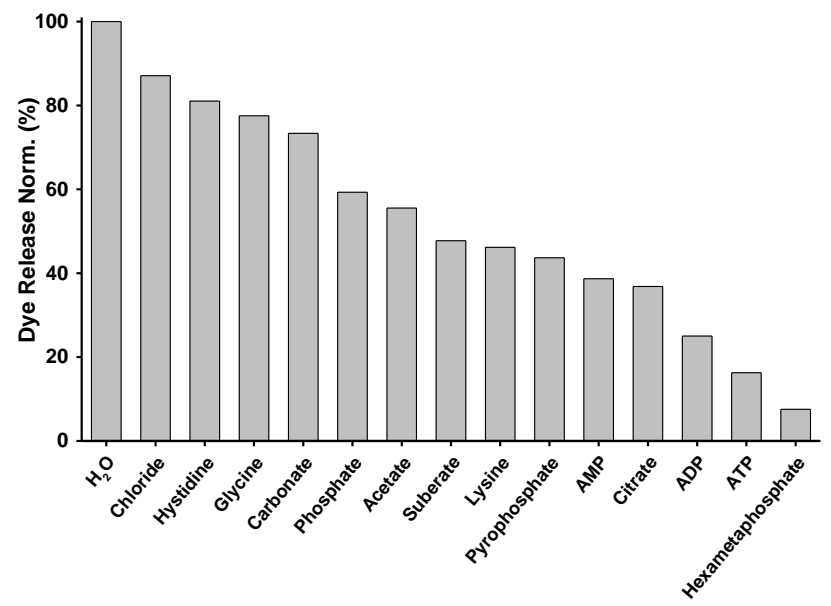

Figure 4. Release profiles of the $\left[\mathrm{Ru}(\mathrm{bipy})_{3}\right]^{2+}$ complex from solid SC2 in water at $\mathrm{pH} 7.0$ alone and in the presence of selected anions and amino acids $\left(1.0 \times 10^{-4} \mathrm{M}\right)$ after $15 \mathrm{~h}$.

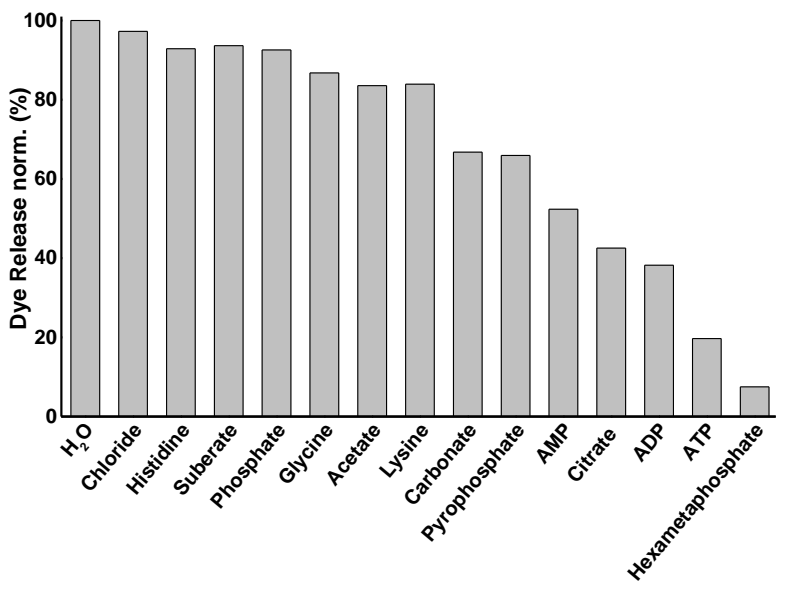

Figure 5. Release profiles of the $\left[\mathrm{Ru}(\text { bipy })_{3}\right]^{2+}$ complex from solid SC3 in water at $\mathrm{pH} 7.0$ alone and in the presence of selected anions and amino acids $\left(1.0 \times 10^{-4} \mathrm{M}\right)$ after $15 \mathrm{~h}$.

Similar inhibition trends were observed upon the addition of selected amino acids and anions to aqueous suspensions of solids SC2 and SC3 (see Figures 4 and 5, respectively). As seen, a higher degree on delivery inhibition was observed in the presence of highly charged and bulky anions ATP and hexametaphosphate. The slight 
differences noted in cargo inhibition exhibited by the three solids (i.e. SC1, SC2, and SC3) in the presence of anions may be due to specific local interactions between anions and the different complexes (i.e. $\mathbf{C 1}, \mathbf{C 2}$ and $\mathbf{C 3}$ ) anchored to the external surface.

In order to highlight the crucial role played by $\mathbf{C 1}, \mathbf{C 2}$, and $\mathbf{C 3}$ in the anion-controlled inhibition protocol, the cargo delivery from SC1, SC2 and SC3 was compared with that from solid S0 (the MCM-41 nanoparticles loaded with $\left[\mathrm{Ru}(\text { bipy })_{3}\right]^{2+}$ and with no complex grafted onto the outer surface) and S10 (the MCM-41 nanoparticles loaded with $\left[\mathrm{Ru}(\mathrm{bipy})_{3}\right]^{2+}$ and with macrocycle $\mathbf{1 0}$ anchored to the surface). For both nanoparticles, a sustained $\left[\mathrm{Ru}(\text { bipy })_{3}\right]^{2+}$ release took place over time in the absence or presence of all the selected anions and amino acids at $1.0 \times 10^{-4} \mathrm{M}$ (data not shown). The absence of any $\mathrm{Cu}^{\mathrm{II}}$ complex anchored to the external surface of nanoparticles resulted in neither interactions with anions nor pore blockage.

Specific experiments were also performed in order to rule out any possible direct influence of added anions on the emission of $\mathrm{Ru}$ probe. For instance, an aqueous solution of $\left[\mathrm{Ru}(\text { bipy })_{3}\right] \mathrm{Cl}_{2}$ $\left(1 \times 10^{-4} \mathrm{M}\right)$ was treated with increasing amounts of hexamethaphosphate (up to 100 eq.) and emission intensity was measured after each addition without observing any detectable change. The same experiment was repeated with the different anionic species considered in this work and no quenching process was observed. Therefore, it can be stated that anions do not affect the fluorescence of the $\mathrm{Ru}^{\mathrm{II}}$ complex and the fluorescence variation is only due to the dye releasing.

It should be also noted that fluorescence measurements were always performed after centrifugation and the emission intensity data were always related to the resulting clear solution. Therefore, any influence of scattering can be ruled out.

The relationship between inhibition of dye delivery and anion features (charge and size), which was suggested by experimental results, can be highlighted by plotting the $\%$ of $\left[\operatorname{Ru}(\text { bipy })_{3}\right]^{2+}$ released from hybrid materials $v$ s. the product of anion average charge at a neutral $\mathrm{pH}$ and its diameter expressed in $\AA$ (considering anions to be smooth spheres). As an example, the plot obtained in the case of solid SC1 is reported in Figure 6. It show a remarkable linear correlation: highly charged and bulky anionic species (such as ATP and hexametaphosphate) induce strong delivery inhibition, whereas smaller and less charged anions (chloride, acetate) are unable to block pores to a certain extent. Similar linear dependences between the degree of inhibition and the [charge $x$ diameter] parameter are observed for solids SC2 and SC3 (see Figures SI-1 and SI-2 in the Supporting Information,).

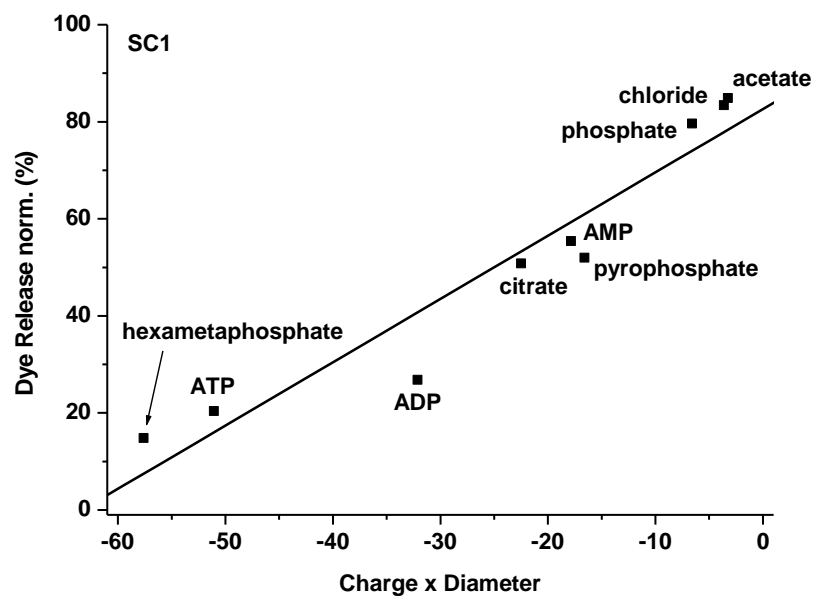

Figure 6. Release of $\left[\mathrm{Ru}(\mathrm{bipy})_{3}\right]^{2+}$ complex (emission band at $610 \mathrm{~nm}$ ) from the suspensions of solid $\mathbf{S C 1}$ at a neutral $\mathrm{pH}$ in the presence of different anionic species $\left(1.0 \times 10^{-4} \mathrm{M}\right) v s$. the product [average charge $\mathrm{x}$ diameter expressed in $\AA$ ] of the selected anions.

The clear influence of anion charge (in addition to anion size) on the inhibition of the $\left[\mathrm{Ru}(\mathrm{bipy})_{3}\right]^{2+}$ release from the interior of the functionalized nanoparticles indicate that interactions involving anionic capping agents and anchored metal complexes have a strong electrostatic character, although the occurrence of metal/ligand as well as H-bond interactions cannot be ruled out.

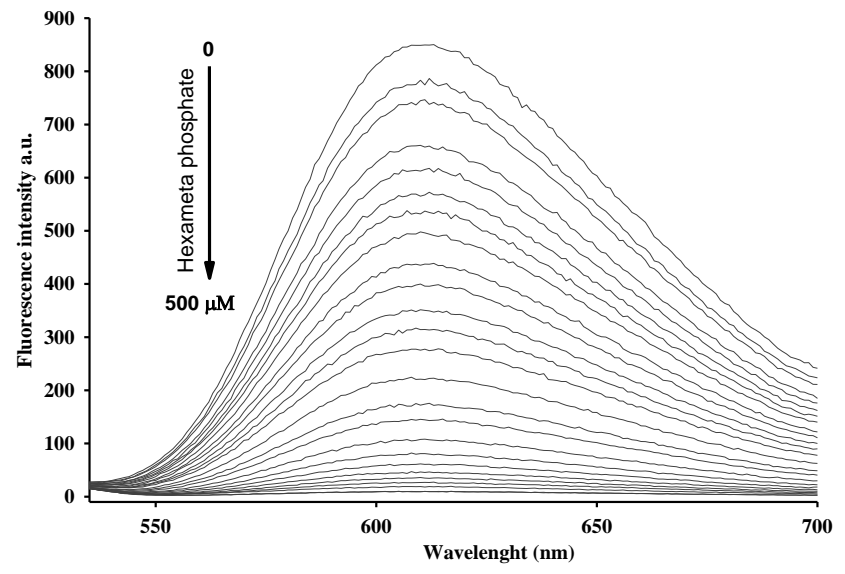

Figure. 7. Changes in the $\left[\mathrm{Ru}(\mathrm{bipy})_{3}\right]^{2+}$ emission band (excitation at 451 $\mathrm{nm}$ ) in the presence of increasing amounts of hexametaphosphate in water suspensions of the SC3 nanoparticles at pH 7.0 (after $15 \mathrm{~h}$ ).

After assessing the good efficiency of the hexametaphosphate anion during the inhibition of dye delivery, the emission of the $\left[\mathrm{Ru}(\text { bipy })_{3}\right]^{2+}$ released from nanoparticles SC1, SC2 and $\mathbf{S C 3}$ in water suspensions at $\mathrm{pH} 7.0$ was measured (after $15 \mathrm{~h}$ ) in the presence of different (increasing) quantities of hexametaphosphate. The fluorescence response of the three solids was similar, and the delivery of the entrapped $\left[\mathrm{Ru}(\mathrm{bipy})_{3}\right]^{2+}$ was proportional to the hexametaphosphate anion concentration in all cases. As an example, Figure 7 shows the different emission spectra recorded in the case of solid SC3. Spectra observed during similar experiment carried out on SC1 And SC2 are reported in Figures SI-3 and SI-4. At a low hexametaphosphate concentration, a remarkable release of the entrapped cargo was still observed, whereas the intensity of $\left[\mathrm{Ru}(\mathrm{bipy})_{3}\right]^{2+}$ emission band decreased in the presence of larger anion concentrations due to hexametaphosphate-induced pore closure. The corresponding profile obtained by plotting fluorescence intensity vs anion concentration indicates that pores blocking starts at hexametaphosphate concentration of $3 \mu \mathrm{M}$ (see figure SI-5 Supporting Information). In the case of solids SC1 and SC2 the hexametaphosphate concentration values at which the dye inhibition release starts to take place are 5 and $9 \mu \mathrm{M}$, respectively.

Opening the gate in hexametaphosphate-capped supports: In the previous section, we demonstrated that hybrid materials SC1, SC2, and SC3 were able to display controlled mass delivery, which can be finely tuned by the interaction of certain anions with the $\mathrm{Cu}^{\text {II }}$ metal complexes anchored to the surface of solids. We also found that bulky and highly charged anions, such as hexametaphosphate, were able to inhibit cargo release. Based on this observation, it was easy to prepare capped solids SC1-mPh and SC3-mPh via the simple addition of sodium hexametaphosphate to suspensions of 
nanoparticle SC1 or SC3, respectively. The synthesis of SC3-mPh has been recently published by our group as a short communication. ${ }^{[36]}$

In a similar way to the study reported in the previous section, in which the gating effect of different anions on solids SC1, SC2, and SC3 was investigated, we performed further experiments in order to seek which species could induce cargo delivery in capped solids SC1-mPh and SC3-mPh.

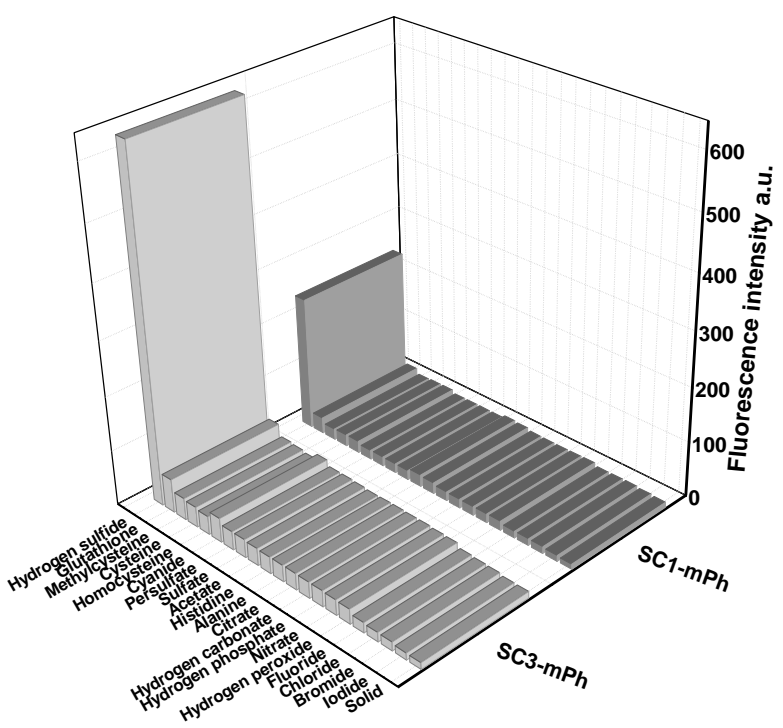

Figure 8. Fluorescence intensity at $610 \mathrm{~nm}$ of the $\left[\mathrm{Ru}(\text { bipy })_{3}\right]^{2+}$ complex delivered from solids SC1-mPh and SC3-mPh (pH 7.5, HEPES $10 \mathrm{mM}$ ) after $6 \mathrm{~h}$ of adding selected chemicals $(1 \mathrm{mM})$.

Solids SC1-mPh and SC3-mPh were characterised following standard procedures. The PXRD patterns of both solids are shown in Figure 1 (curves $\mathrm{f}$ and g). Both hexametaphosphate-capped solids exhibited the characteristic (100) reflection, which indicates that the mesoporous structure was preserved throughout the preparation sequence. The TEM images (see Figure 1k for solid SC3-mPh) revealed that final solids looked like spheres of ca. $100 \mathrm{~nm}$. The $\mathrm{N}_{2}$ adsorption-desorption isotherms of SC1-mPh and SC3-mPh were typical of mesoporous systems with partially filled pores, and a drastic decrease of the adsorbed $\mathrm{N}_{2}$ volume and of the specific surface was observed compared with the starting MCM-41 material (see Table 1). The organic contents in solids SC1-mPh and SC3-mPh were calculated by elemental and thermogravimetric analyses, and are shown in Table 2.

Studies of $\left[\mathrm{Ru}(\text { bipy })_{3}\right]^{2+}$ dye release from solids $\mathbf{S C 1}-\mathbf{m P h}$ and SC3-mPh alone and in the presence of a collection of selected anions ( $\mathrm{HS}^{-}, \mathrm{F}^{-}, \mathrm{Br}-, \mathrm{Cl}^{-}, \mathrm{I}^{-}, \mathrm{CN}^{-}, \mathrm{HPO}_{4}{ }^{2-}, \mathrm{AcO}^{-}$, citrate, $\mathrm{NO}_{3}{ }^{-}$, $\mathrm{HCO}_{3}{ }^{-}, \mathrm{SO}_{4}{ }^{2-}$ and $\mathrm{S}_{2} \mathrm{O}_{8}{ }^{2-}$ ), amino acids (alanine and histidine), thiol-containing biomolecules (cysteine, methylcysteine, homocysteine and GSH) and oxidants $\left(\mathrm{H}_{2} \mathrm{O}_{2}\right)$ were carried out. In a typical experiment, $1 \mathrm{mg}$ of SC1-mPh or SC3-mPh was suspended in $2 \mathrm{~mL}$ of buffered solution (pH 7.5, HEPES $10 \mathrm{mM}$ ) in the absence and presence of the above-described species (1 $\mathrm{mM}$ ). Dye delivery to the bulk solution was easily detected by monitoring the emission band of $\left[\mathrm{Ru}(\text { bipy })_{3}\right]^{2+}$, centred at 610 $\mathrm{nm}$ upon excitation at $451 \mathrm{~nm}$ in the solution after removing the solid by centrifugation. The results obtained for both solids are depicted in Figure 8. As seen, solids SC1-mPh or SC3-mPh showed negligible dye release due to interactions between the grafted $\mathbf{C 1}$ and $\mathbf{C 3}$ complexes and the hexametaphosphate anion. Figure 8 clearly indicates that none of the chemicals tested, except hydrogen sulphide, was able to induce remarkable cargo delivery in both solids. Release of the entrapped $\left[\mathrm{Ru}(\mathrm{bipy})_{3}\right]^{2+}$ is ascribed to an hydrogen sulphide-induced demetallation reaction of the anchored $\mathbf{C 1}$ and $\mathbf{C 3}$ complexes, which resulted in the subsequent rupture of the anion-cation adduct and in the release of $\left[\mathrm{Ru}(\mathrm{bipy})_{3}\right]^{2+} \cdot{ }^{[37]}$ This proposed paradigm is shown in Scheme 1 .

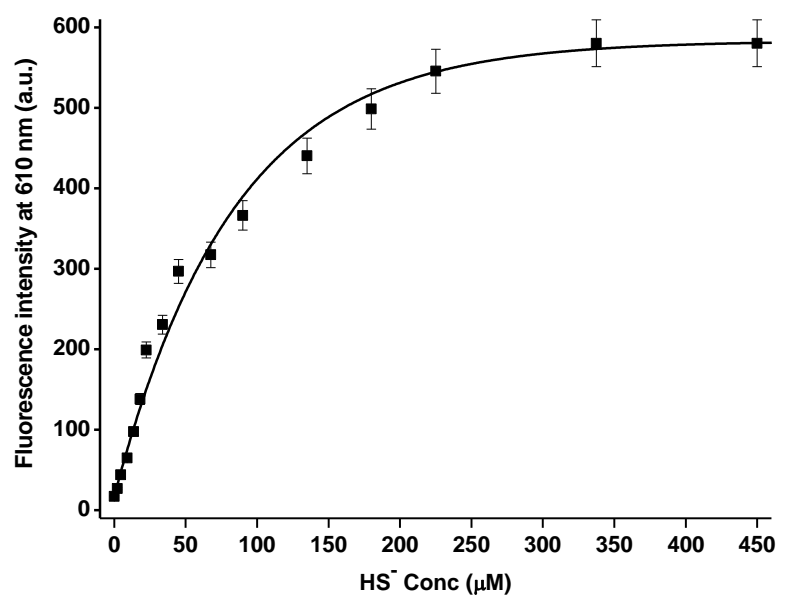

Figure 9. Calibration curve of the $\left[\mathrm{Ru}(\text { bipy })_{3}\right]^{2+}$ complex delivered from SC1-mPh (pH 7.5, HEPES $10 \mathrm{mM}$ ) upon the addition of increasing quantities of the hydrogen sulphide anion.

In order to further characterize this selective opening in the presence of hydrogen sulphide, the fluorogenic response of nanoparticles SC1-mPh and SC3-mPh was studied in the presence of increasing quantities of $\mathrm{HS}^{-}$. As shown in Figure 9, a clear correlation between the emission enhancement and the amount of hydrogen sulphide added to solid SC1-mPh was observed (a similar result was obtained for nanoparticles SC3$\mathbf{m P h}$ ), which was in agreement with an uncapping protocol involving a demetallation reaction. From the fluorescence intensity/[HS $\left.{ }^{-}\right]$profiles, it was found that the minimum amount of hydrogen sulphide required to start gate opening and cargo delivery was 2.25 and $1.85 \mu \mathrm{M}$ for nanoparticle SC1-mPh and SC3-mPh, respectively. Both concentrations are below the hydrogen sulphide concentration required to elicit physiological responses $(10-1000 \mathrm{mM}) .^{[38]}$

Note that solids SC1-mPh and SC3-mPh were capped materials capable of delivering the cargo only in the presence of a certain analyte (hydrogen sulphide in our case). This was the basis to design probes for the chromo-fluorogenic detection of the target species using gated materials. Therefore, both SC1-mPh and SC3-mPh supports could be potentially used for this sensing application. ${ }^{[6,7]}$

\section{Conclusions}

In summary, we report herein the synthesis of three solids (SC1, SC2 and SC3) constructed using MCM-41 silica nanoparticles as an inorganic scaffold. The inorganic support pores were loaded with the $\left[\mathrm{Ru}(\text { bipy })_{3}\right]^{2+}$ dye and the outer surface was functionalized with three different macrocyclic $\mathrm{Cu}^{\mathrm{II}}$ complexes $(\mathrm{C1}, \mathrm{C} 2$ and $\mathbf{C 3}$ for $\mathbf{S C 1}$, SC2 and SC3, respectively). The release of the $\left[\mathrm{Ru}(\text { bipy })_{3}\right]^{2+}$ dye 
from the interior of the pores of the three materials was studied in the presence of selected anions (chloride, hydrogencarbonate, acetate, suberate, citrate, hydrogenphosphate, pyrophosphate, hexametaphosphate, AMP, ADP, and ATP) and amino acids (glycine, histidine and lysine). Small monovalent, divalent anions and amino acids were unable to inhibit dye release, whereas the presence of bulky and highly charged anions (especially ATP and hexametaphosphate) significantly inhibited cargo release. The hindered $\left[\mathrm{Ru}(\mathrm{bipy})_{3}\right]^{2+}$ release was ascribed to the formation of the complexes between the grafted copper(II)-macrocycles and the added anions. Besides, two new nano-sized hybrid materials, SC1$\mathbf{m P h}$ and $\mathbf{S C 3}-\mathbf{m P h}$, were prepared by adding the hexametaphosphate anion to solids SC1 and SC3. SC1-mPh and SC3-mPh are capped systems that show no cargo release. The presence of a collection of selected anions $\left(\mathrm{F}^{-}, \mathrm{Br}^{-}, \mathrm{Cl}^{-}, \mathrm{I}^{-}, \mathrm{CN}^{-}\right.$, $\mathrm{HPO}_{4}^{-}, \mathrm{AcO}^{-}$, citrate, $\mathrm{NO}_{3}{ }^{2-}, \mathrm{HCO}_{3}{ }^{-}, \mathrm{SO}_{4}{ }^{2-}$ and $\mathrm{S}_{2} \mathrm{O}_{8}{ }^{2-}$ ), amino acids (alanine and histidine), thiol-containing biomolecules (cysteine, methylcysteine, homocysteine and GSH) and oxidants $\left(\mathrm{H}_{2} \mathrm{O}_{2}\right)$ was unable to open gated materials, whereas cargo release was selectively observed in the presence of hydrogen sulphide due to a demetallation reaction. These studies indicate the importance of the presence of anions in gated ensembles built with metal complexes in cargo delivery terms. We believe that our findings could be of importance for the future design of gated materials in which anions are present in the solution, especially when the gating ensemble is positively charged.

\section{Experimental Section}

Reagents: Chemicals (ethylendiamine, di-tert-butyl-dicarbonate, triethylamine, pyridine, (3-isocyanatopropyl)triethoxysilane, 2,6 diacetylpyridine, $\mathrm{NaBH}_{4}, 3,3$ '-iminobis(propylamine), formaldehyde, aqueous $60 \% \quad \mathrm{HClO}_{4}$, tetraethylorthosilicate (TEOS), ncetyltrimethylammonium bromide $(\mathrm{CTABr}), \quad\left[\mathrm{Ru}(\text { bipy })_{3}\right] \mathrm{Cl}_{2}$, thiols, selected amino acids, and all inorganic salts) were provided by SigmaAldrich. Analytical-grade solvents were purchased from Scharlab (Barcelona, Spain). All the reagents were used as received.

Macrocyclic copper(II) complexes $\mathbf{4}$ and $\mathbf{6}$ were prepared and isolated as perchlorate salts $\left(\mathbf{4} \cdot\left(\mathrm{ClO}_{4}\right)_{3}\right.$ and $\mathbf{6} \cdot\left(\mathrm{ClO}_{4}\right)_{4}$, respectively), according to previously reported procedures. ${ }^{[24 \mathrm{c}]}$

Methods: ${ }^{1} \mathrm{H}$ NMR spectra were recorded in a Varian Gemini $300 \mathrm{MHz}$ NMR spectrometer. Mass spectra were acquired on a Thermo-Finnigan iontrap LCQ Advantage Max instrument equipped with an ESI source. UV/Vis absorption measurements were measured with a Perkin-Elmer Lambda-35 spectrometer. Fluorescence behaviour was studied with an FS900CDT Steady State T-Geometry Fluorimeter from Edinburgh Analytical Instruments. X-ray measurements were taken on a Brüker AXS D8 Advance diffractometer using $\mathrm{CuK} \alpha$ radiation. Thermogravimetric analyses were carried out on TGA/SDTA 851e Mettler Toledo equipment, using an oxidant atmosphere (Air, $80 \mathrm{~mL} / \mathrm{min}$ ) with a heating programme, consisting in a heating ramp of $10^{\circ} \mathrm{C}$ per minute from $393 \mathrm{~K}$ to $1273 \mathrm{~K}$ and an isothermal heating step at this temperature for 30 minutes. The TEM images were taken with a JEOL TEM-1010 electron microscope that worked at $100 \mathrm{kV}$. $\mathrm{N}_{2}$ adsorption-desorption isotherms were recorded on a Micromeritics ASAP2010 automated sorption analyser. Samples were degassed at $120^{\circ} \mathrm{C}$ in vacuum overnight. Specific surface areas were calculated from the adsorption data within the low pressures range using the BET model. Pore diameter was determined following the BJH method.

Synthesis of silica mesoporous nanoparticles: ncetyltrimethylammoniumbromide (CTABr, $1.0 \mathrm{~g}, 2.74 \mathrm{mmol})$ was first dissolved in $480 \mathrm{~mL}$ of distilled water. Then $3.5 \mathrm{~mL}$ of $\mathrm{NaOH} 2.00 \mathrm{M}$ in distilled water were added to the CTABr solution, and then the solution temperature was adjusted to $80^{\circ} \mathrm{C}$. TEOS $\left(5 \mathrm{~mL}, 2.57 \times 10^{-2}\right.$ mol $)$ was then added dropwise to the surfactant solution. The mixture was stirred for $2 \mathrm{~h}$ to give a white precipitate. Finally the solid product was centrifuged, washed with distilled water and dried at $60^{\circ} \mathrm{C}$ (MCM-41 as-synthesized). To prepare the final porous material (MCM-41), the as-synthesised solid was calcinated at $550^{\circ} \mathrm{C}$ in an oxidant atmosphere for $5 \mathrm{~h}$ to remove the template phase.

Synthesis of 1: Ethylendiamine $(5.84 \mathrm{ml}, 87 \mathrm{mmol})$ was dissolved in 1.4dioxane $(30 \mathrm{~mL})$ in a $250 \mathrm{~mL}$ round-bottomed flask. Then a solution of ditert-butyl-dicarbonate $(2.45 \mathrm{~g}, 11 \mathrm{mmol})$ in 1.4-dioxane $(30 \mathrm{~mL})$ was added for $2 \mathrm{~h}$ through a dropping funnel. The final mixture was stirred for $24 \mathrm{~h}$ at room temperature. After solvent evaporation, crude oil was suspended in water $(50 \mathrm{~mL})$ and then extracted with dichloromethane $(3 \times 50 \mathrm{~mL})$. The organic phase was dried with $\mathrm{Na}_{2} \mathrm{SO}_{4}$, filtered and evaporated to dryness using a high vacuum pump. Yield: $19 \%$. ESI-MS: $\mathrm{m} / \mathrm{z}=161(100 \%)(\mathrm{M}+1)$. ${ }^{1} \mathrm{H}-\mathrm{NMR}\left(300 \mathrm{MHz}, \mathrm{CD}_{3} \mathrm{OD}\right): \delta 3.15(\mathrm{t}, \mathrm{J}=6 \mathrm{~Hz}, 2 \mathrm{H}), 2.74(\mathrm{t}, \mathrm{J}=6 \mathrm{~Hz}, 2 \mathrm{H})$, $1.40(\mathrm{~s}, 9 \mathrm{H})$.

Synthesis of complex $\mathbf{C 1 :} \mathbf{4} \cdot\left(\mathrm{ClO}_{4}\right)_{3}(0.81 \mathrm{~g}, 1.33 \mathrm{mmol})$ was dissolved in dry acetonitrile $(30 \mathrm{~mL})$. Then triethylamine $(0.74 \mathrm{~mL}, 5.32 \mathrm{mmol})$ and pyridine $(0.43 \mathrm{~mL}, 5.32 \mathrm{mmol})$ were added to the resulting solution. (3isocyanatopropyl)triethoxysilane $(\mathbf{5}, 0.33 \mathrm{~g}, 1.33 \mathrm{mmol})$ was dissolved in dry acetonitrile $(20 \mathrm{~mL})$ and dropped into the solution of complex 4 . The resulting mixture was stirred for $5 \mathrm{~h}$ at room temperature. The complex salt C1 $\cdot\left(\mathrm{ClO}_{4}\right)_{2}$ was obtained as a pink precipitate, which was separated by filtration, and washed with acetonitrile $(10 \mathrm{~mL})$. Yield: $70 \%$. ESI-MS: m/z = $655(100 \%) \quad\left[\mathrm{M}+\mathrm{ClO}_{4}^{-}\right]^{+} . \quad\left[\mathrm{M}+\mathrm{ClO}_{4}^{-} ;\right.$calcd. for $\mathrm{C}_{21} \mathrm{H}_{49} \mathrm{ClCuN}_{7} \mathrm{O}_{8} \mathrm{Si}$ : 655.5159]. UV-Vis (acetonitrile): $\lambda_{\max }=501 \mathrm{~nm}, \varepsilon=68 \mathrm{M}^{-1} \mathrm{~cm}^{-1}$.

Synthesis of solid SC1: Calcined MCM-41 (500 mg) and $\left[\mathrm{Ru}(\text { bipy })_{3}\right]^{2+}$ dye $(140.34 \mathrm{mg}, 0.40 \mathrm{mmol})$ were suspended in acetonitrile $(20 \mathrm{~mL})$ in a roundbottomed flask. The mixture was stirred for $24 \mathrm{~h}$ at room temperature, filtered off and dried under vacuum. Afterwards, this loaded solid (S0, 400 $\mathrm{mg}$ ) was re-suspended in acetonitrile $(10 \mathrm{~mL})$ containing $\left[\mathrm{Ru}(\text { bipy })_{3}\right]^{2+}(30$ $\mathrm{mg}$ ) and complex $\mathbf{C 1}$ (1.5 g, $2.3 \mathrm{mmol}$ ) was added. After stirring for $12 \mathrm{~h}$ at room temperature, the resulting solid was filtered off then dried under vacuum, washed with acetronitrile $(10 \mathrm{~mL})$ and diethyl ether $(10 \mathrm{~mL})$, and was finally dried at $40^{\circ} \mathrm{C}$ for $12 \mathrm{~h}$.

Synthesis of complex C2: $\mathbf{6} \cdot\left(\mathrm{ClO}_{4}\right)_{4}(1.00 \mathrm{~g}, 2.30 \mathrm{mmol})$ was dissolved in acetonitrile $(30 \mathrm{~mL})$. Then triethylamine $(0.74 \mathrm{ml}, 5.32 \mathrm{mmol})$ and pyridine $(0.43 \mathrm{ml}, 5.32 \mathrm{mmol})$ were added to the mixture. Afterward, (3isocyanatopropyl)triethoxysilane $(\mathbf{5}, 1.10 \mathrm{~g}, 4.50 \mathrm{mmol})$ was dissolved in acetonitrile $(20 \mathrm{~mL})$ and added to the previous mixture. The final solution was stirred for $5 \mathrm{~h}$ at room temperature. The complex salt $\mathbf{C 2} \cdot\left(\mathrm{ClO}_{4}\right)_{2}$ was obtained as a pink precipitate that was filtered off and washed with $10 \mathrm{~mL}$ of dry MeCN. Yield: $80 \%$. ESI-MS: $\mathrm{m} / \mathrm{z}=945.61(100 \%)\left[\mathrm{M}^{2+}+\mathrm{ClO}_{4}^{-}\right]^{+}$, $423.26(30 \%)\left[\mathrm{M}^{2+}\right]^{2+}$. UV-Vis (acetonitrile) $\lambda_{\max }=500 \mathrm{~nm}, \varepsilon=78 \mathrm{M}^{-1} \mathrm{~cm}^{-1}$. Synthesis of solid SC2: MCM-41 (400 mg) loaded with the dye was resuspended in acetonitrile $(10 \mathrm{~mL})$ that contained $\left[\mathrm{Ru}(\text { bipy })_{3}\right]^{2+}(50 \mathrm{mg})$ and complex C2 (2.0 g, $2.2 \mathrm{mmol}$ ) was added. After stirring for $12 \mathrm{~h}$ at room temperature, the resulting solid was filtered off then dried under vacuum, washed with acetronitrile $(10 \mathrm{~mL})$ and diethyl ether $(10 \mathrm{~mL})$. Finally it was dried at $40^{\circ} \mathrm{C}$ for $12 \mathrm{~h}$.

Synthesis of 9: 3,3'-iminobis(propylamine) (7, $0.658 \mathrm{~g}, 5.02 \mathrm{mmol}$ ) was dissolved in methanol $(50 \mathrm{~mL})$ and slowly added to a stirred solution of 2,6 diacetylpyridine $(\mathbf{8}, 0.82 \mathrm{~g}, 5.02 \mathrm{mmol})$ in methanol $(200 \mathrm{~mL})$. The solution was stirred and refluxed for $1 \mathrm{~h}$ and then $\mathrm{NaBH}_{4}(0.57 \mathrm{~g}, 15.1 \mathrm{mmol})$ was slowly added to the stirred solution. The solvent was evaporated to yield an oil, which was purified by column chromatography $\left(\mathrm{CHCl}_{3} / \mathrm{MeOH} 75: 25\right)$ on silica gel to give 9. Yield: 78\%. ${ }^{1} \mathrm{H}$ NMR $\left(400 \mathrm{MHz}, \mathrm{CDCl}_{3}\right) \delta 7.67-7.40(\mathrm{~m}$, $1 \mathrm{H}), 7.06(\mathrm{~m}, J=7.7 \mathrm{~Hz}, 1 \mathrm{H}), 6.98(\mathrm{~d}, J=7.6 \mathrm{~Hz}, 1 \mathrm{H}), 3.82(\mathrm{t}, J=6.7 \mathrm{~Hz}$, $2 \mathrm{H}), 3.73(\mathrm{t}, J=6.8 \mathrm{~Hz}, 1 \mathrm{H}), 2.97-2.81(\mathrm{~m}, 2 \mathrm{H}), 2.63(\mathrm{~m}, J=7.2,4.1 \mathrm{~Hz}$, $8 \mathrm{H}), 2.47(\mathrm{~s}, 2 \mathrm{H}), 2.34(\mathrm{~d}, J=3.3 \mathrm{~Hz}, 2 \mathrm{H}), 1.39(\mathrm{dd}, J=23.9,6.7 \mathrm{~Hz}, 6 \mathrm{H})$. ESI-MS: $\mathrm{m} / \mathrm{z}=263.39(\mathrm{M}+1)^{+}$.

Synthesis of 10: (3-isocyanatopropyl)triethoxysilane $(\mathbf{5}, 0.33 \mathrm{~g}, 1.33 \mathrm{mmol})$ dissolved in acetonitrile $(10 \mathrm{~mL})$ was slowly added to a solution of $9(0.35 \mathrm{~g}$, $1.33 \mathrm{mmol})$ in an acetonitrile-toluene-chloroform 1:1:0.1 mixture $(50 \mathrm{~mL})$. The solution was stirred at for $1 \mathrm{~h}$ at $0^{\circ} \mathrm{C}$ and at room temperature for another hour. Evaporation of solvent provided a yellow oil, which solidified after repeated washings with diethyl ether. Yield: $80 \% .{ }^{1} \mathrm{H}$ NMR $(400 \mathrm{MHz}$, $\left.\mathrm{CDCl}_{3}\right) \delta 7.62(\mathrm{t}, J=7.7 \mathrm{~Hz}, 1 \mathrm{H}), 7.09$ (d, $\left.J=7.7 \mathrm{~Hz}, 1 \mathrm{H}\right), 7.00(\mathrm{~d}, J=7.5$ $\mathrm{Hz}, 1 \mathrm{H}), 3.95-3.83(\mathrm{~m}, 1 \mathrm{H}), 3.71(\mathrm{~d}, J=7.0 \mathrm{~Hz}, 4 \mathrm{H}), 2.94(\mathrm{~d}, J=8.9 \mathrm{~Hz}$, 
1H), 2.80-2.56 (m, 4H), $2.52(\mathrm{~s}, 1 \mathrm{H}), 2.37(\mathrm{~s}, 1 \mathrm{H}), 1.83(\mathrm{~d}, J=30.1 \mathrm{~Hz}, 5 \mathrm{H})$, $1.45(\mathrm{~d}, J=6.7 \mathrm{~Hz}, 4 \mathrm{H}), 1.38(\mathrm{~d}, J=6.7 \mathrm{~Hz}, 3 \mathrm{H}), 1.24$ (s, 6H). ESI-MS: m/z $=510.00(\mathrm{M}+1)^{+}$

Synthesis of complex C3: To a solution of $\mathbf{1 0}(0.800 \mathrm{~g}, 1.56 \mathrm{mmol})$ in acetonitrile $(30 \mathrm{~mL})$, copper(II) perchlorate hexahydrate $(0.60 \mathrm{~g}, 1.62 \mathrm{mmol})$ was added and the resulting mixture was stirred at room temperature for $2 \mathrm{~h}$. The solution was concentrated in vacuo and complex $\mathbf{C 3}$ was obtained as the corresponding blue perchlorate salt, $\mathbf{C 3} \cdot\left(\mathrm{ClO}_{4}\right)_{2}$. Yield: $95 \%$. ESI-MS: $\mathrm{m} / \mathrm{z}=$ $673.20(100 \%)\left[\mathrm{M}^{2+}+\mathrm{ClO}_{4}^{-}\right]^{+}$.

Synthesis of solid SC3: Calcined MCM-41 (500 mg) and the $\left[\mathrm{Ru}(\mathrm{bipy})_{3}\right]^{2+}$ dye $(140.34 \mathrm{mg}, 0.40 \mathrm{mmol})$ were suspended in acetonitrile $(20 \mathrm{~mL})$ in a round-bottomed flask. The mixture was stirred for $24 \mathrm{~h}$ at room temperature, filtered off and dried under vacuum. Charged MCM-41 (400 mg) was resuspended in dry acetonitrile $(10 \mathrm{~mL})$ containing $\left[\mathrm{Ru}(\text { bipy })_{3}\right]^{2+}(50 \mathrm{mg})$ and complex C3 (1.54 g, $2.1 \mathrm{mmol}$ ). After stirring for $12 \mathrm{~h}$ at room temperature, the resulting solid was filtered off and then dried under vacuum, washed with acetonitrile $(10 \mathrm{~mL})$, diethyl ether $(10 \mathrm{~mL})$ and dried at $40^{\circ} \mathrm{C}$ for $12 \mathrm{~h}$.

Synthesis of solids SC1-mPh and SC3-mPh: SC1 or SC3 were suspended in distilled water $(20 \mathrm{~mL})$ that contained $\left[\mathrm{Ru}(\text { bipy })_{3}\right]^{2+}(10 \mathrm{mg})$ and sodium hexametaphosphate $(2 \mathrm{~g}, 3.4 \mathrm{mmol})$. The suspension was stirred at room temperature for $2 \mathrm{~h}$, filtered, washed with water $(10 \mathrm{~mL})$ and dried under vacuum for $12 \mathrm{~h}$.

Synthesis of solid S10: Calcined MCM-41 (100 mg) and [Ru(bipy $\left.)_{3}\right]^{2+}$ dye (30 $\mathrm{mg}, 0.08 \mathrm{mmol})$ were suspended in acetonitrile $(10 \mathrm{~mL})$ in a roundbottomed flask. The mixture was stirred for $24 \mathrm{~h}$ at room temperature, filtered and the recovered solid was dried under vacuum. Afterwards, this loaded solid $(80 \mathrm{mg})$ was re-suspended in acetonitrile $(10 \mathrm{~mL})$ containing $\left[\mathrm{Ru}(\text { bipy })_{3}\right]^{2+}(5 \mathrm{mg})$ and $\mathbf{1 0}(300 \mathrm{~g}, 0.59 \mathrm{mmol})$ was added. After stirring for $12 \mathrm{~h}$ at room temperature, the resulting solid was filtered off, then dried under vacuum, washed with acetronitrile $(5 \mathrm{~mL})$ and diethyl ether $(5 \mathrm{~mL})$, and was finally dried at $40^{\circ} \mathrm{C}$ for $12 \mathrm{~h}$.

\section{Acknowledgements}

Financial support from the Spanish Government (Project MAT2012-38429C04-01) and the Generalitat Valencia (Project PROMETEO/2009/016) is gratefully acknowledged.

[1] (a) A. B. Descalzo, R. Martínez-Máñez, F. Sancenón, K. Hoffmann, K. Rurack, Angew. Chem. Int. Ed. 2006, 45, 5924-5948; (b) M. -P. Santoni, G. S. Hanan, B. Hasenknopf, Coord. Chem. Rev. 2014, 281, 64-85; (c) F. Hoffmann, M. Cornelius, J, Morell, M. Fröba, Angew. Chem. Int. Ed. 2006 45, 3216-3251.

[2] (a) E. Aznar, R. Martínez-Máñez, F. Sancenón, Expert Opin. Drug Deliv. 2009, 6, 643-655; (b) S. Alberti, G. J. A. A. Soler-Illia, O. Azzaroni, Chem Commun, 2015, 51, 6050-6075.

[3] E. Aznar, M. Oroval, Ll. Pascual, J. R. Murguía, R. Martínez-Máñez, F. Sancenón, Chem. Rev. 2016, DOI: 10.1021/acs.chemrev.5b00456.

[4] (a) J. A. Barreto, W. O’Malley, M. Kubeil, B. Graham, H. Stephan, L. Spiccia, Adv. Mater. 2011, 23, H18-H40; (b) Z. Li, J. C. Barnes, A. Bosoy, J. F. Stoddart, J. I. Zink, Chem. Soc. Rev. 2012, 41, 2590-2605; (c) C. -H. Lu, B. Willner, I. Willner, ACS Nano 2013, 7, 8320-8332; (d) S. Koutsopoulos, Adv. Drug Deliver. Rev. 2012, 64, 1459-1476; (e) Y. Chen, H. Chen, J. Shi, Adv. Mater. 2013, 25, 3144-3176; (e) Q. He, J. Shi, Adv. Mater. 2014, 26, 391-411; (f) K. M. L. Taylor-Pashow, J. Della Rocca, R. C. Huxford, W. Lin, Chem. Commun. 2010, 46, 5832-5849; (g) J. M. Rosenholm, C. Sahlgren, M. Lindén, J. Mater. Chem. 2010, 20, 2707-2713; (h) C. Y. Ang, C. S. Y. Tan, Y. Zhao, Org. Biomol. Chem. 2014, 12, 4776-4806.

[5] (a) A. Stein, Adv. Mater. 2013, 15, 763-775; (b) A. P. Wight, M. E. Davis, Chem. Rev. 2002, 102, 3589-3614; (c) G. Kickelbick, Angew. Chem. Int. Ed. 2004, 43, 3102-3104.

[6] C. Coll, A. Bernardos, R. Martínez-Máñez, F. Sancenón, Acc. Chem. Res. 2013, 46, 339-349.

[7] F. Sancenón, Ll. Pascual, M. Oroval, E. Aznar, R. Martínez-Máñez, ChemistryOpen 2015, 4, 418-437.

[8] See for example: (a) R. Casasus, E. Aznar, M. D. Marcos, R. MartínezMáñez, F. Sancenón, J. Soto, P. Amorós, Angew. Chem. Int. Ed. 2006, 45,
6661-6664; (b) C. Coll, R. Casasús, E. Aznar, M. D. Marcos, R. MartínezMáñez, F. Sancenón, J. Soto, P. Amorós, Chem. Commun. 2007, 1957-1959. [9] See for example: (a) L. Hou, C. Zhu, X. Wu, G. Chen, D. Tang, Chem. Commun. 2014, 50, 1441-1443; (b) Z. Zhang, F. Wang, D. Balogh, I. Willner J. Mater. Chem. B 2014, 2, 4449-4455; (c) E. Climent, A. Bernardos, R. Martínez-Máñez, A. Maquieira, M. D. Marcos, N. Pastor-Navarro, R. Puchades, F. Sancenón, J. Soto, P. Amorós, J. Am. Chem. Soc., 2009, 131, 14075-14080.

[10] See for example: (a) E. Climent, M. D. Marcos, R. Martinez-Máñez, F. Sancenón, J. Soto, K. Rurack, P. Amorós, Angew. Chem. Int. Ed., 2009, 48, 8519-8522; (b) Y. Wen, L. Xu, C. Li, H. Du, L. Chen, B. Su, Z. Zhang, X. Zhang, Y. Song, Chem. Commun., 2012, 48, 8410-8412; (c) Z. Zhang, D. Balogh, F. Wang, I. Willner, J. Am. Chem. Soc. 2013, 135, 1934-1940.

[11] See for example: (a) V. C. Ozalp, T. Schafer, Chem. Eur. J., 2011, 17, 9893-9896; (b) C. -L. Zhu, C. -H. Lu, X. -Y. Song, H. -H. Yang, X. -R. Wang, J. Am. Chem. Soc., 2011, 133, 1278-1281; (c) E. Aznar, C. Coll, M. D. Marcos, R. Martínez-Máñez, F. Sancenón, J. Soto, P. Amorós, J. Cano, E. Ruiz, Chem. Eur. J., 2009, 15, 6877-6888.

[12] See for example: (a) M. Chen, C. Huang, C. He, W. Zhu, Y. Xu, Y. Lu, Chem. Commun. 2012, 48, 9522-9524; (b) B. Zhang, B. Liu, J. Liao, G. Chen, D. Tang, Anal. Chem. 2013, 85, 9245-9252; (c) L. Chen, Y. Wen, B. Su, J. Di, Y. Song, L. Jiang, J. Mater. Chem. 2011, 12, 13811-13816.

[13] (a) G. J. A. A. Soler-Illia, O. Azzaroni, Chem. Soc. Rev. 2011, 40, $1107-$ 1150; (b) K. Ariga, S. Ishihara, J. Labuta, J. P. Hill, Curr. Org. Chem. 2011, 15, 3719-3733.

[14] (a) E. Aznar, F. Sancenón, M. D. Marcos, R. Martínez-Máñez, P. Stroeve, J. Cano, P. Amorós, Langmuir 2012, 28, 2986-2996; (b) S. El Sayed C. Gimìnez, E. Aznar, R. Martìnez-Màñez, F. Sancenòn, M. Licchelli, Org. Biomol. Chem. 2015, 13,1017-1021.

[15] (a) S. Saha, K. C. -F. Leung, T. D. Nguyen, J. F. Stoddart, J. I. Zink, Adv. Func. Mater. 2007, 17, 685-693; (b) F. Wang, X. Liu, I. Willner, Angew. Chem. Int. Ed. 2015, 54, 1098-1129; (c) N. Song, Y. -W. Yang, Chem. Soc. Rev. 2015, 44, 3474-3504; (d) R. Klajn, J. F. Stoddart, B. A. Grzybowski, Chem. Soc. Rev. 2010, 39, 2203-2237; (e) Y. -W. Yang, Y. -L. Sun, N. Song, Acc. Chem. Res. 2014, 47, 1950-1960; (f) T. D. Nguyen, K. C.-F. Leung, M. Liong, C. D. Pentecost, J. F. Stoddart, J. I. Zink, Org. Lett. 2006, 8, 33633366; (g) K. C.-F. Leung, T. D. Nguyen, J. F. Stoddart, J. I. Zink, Adv. Func. Mater. 2006, 18, 5919-5928.

[16] Y. L. Choi, J. Jaworski, M. L. Seo, S. J. Lee, J. H. Jung, J. Mater. Chem. 2011, 21, 7882-7885.

[17] S. F. Lee, X. M. Zhu, Y. X. J. Wang, S. H. Xuan, Q. H. You, W. H. Chan, C. H. Wong, F. Wang, J. C. Yu, C. H. K. Cheng, K. C. -F. Leung, ACS Appl. Mater. Interfaces 2013, 5, 1566-1574.

[18] P. Bartovsky, A. Ribes, A. Agostini, A. Benito, R. Martínez-Máñez, Inorg. Chim. Acta 2014, 417, 263-269.

[19] D. Jin, J. H. Lee, M. L. Seo, J. Jaworski, J. H. Jung, New J. Chem. 2012, 36 (8), 1616-1620.

[20] D. Tarn, M. Xue, J. I. Zink, Inorg. Chem.2013, 52, 2044-2049.

[21] S. Wu, Q. Deng, X. Huang, X. Du, ACS Appl. Mater. Interfaces 2014, 6, 15217-15223.

[22] L. Xing, H. Zheng, Y. Cao, S. Che, Adv. Mater. 2012, 24, 6433-6437.

[23] (a) P. D. Beer, E. J. Hayes, Coord. Chem. Rev. 2003, 240, 167-189; (b) C. Lodeiro, F. Pina, Coord. Chem. Rev. 2009, 253, 1353-1383; (c) V. Amendola, M. Bonizzoni, D. Esteban-Gomez, L. Fabbrizzi, M. Licchelli, F. Sancenón, A. Taglietti, Coord. Chem. Rev. 2006, 250, 1451-1470; (d) S. Aoki, E. Kimura, Rev. Mol. Biotech. 2002, 90, 129-155; (e) H. T. Ngo, X. Liu, K. A. Jolliffe, Chem. Soc. Rev. 2012, 41, 4928-4965; (f) S. J. Butler, D. Parker, Chem. Soc. Rev. 2013, 42, 1652-1666.

[24] (a) J. W. Steed, Chem. Soc. Rev. 2009, 38, 506-519; (b) C. Bazzicalupi, A. Bianchi, E. García-España, E. Delgado-Pinar, Inorg. Chim. Acta 2014, 417, 3-26; (c) M. Boiocchi, M. Licchelli, M. Milani, A. Poggi, D. Sacchi Inorg. Chem. 2015, 54, 47-58.

[25] (a) D. K. Cabbiness, D. W. Margerum, J. Am. Chem. Soc. 1969, 91, 6540-6541; (b) D. K. Cabbiness, D. W. Margerum, J. Am. Chem. Soc. 1970, 92, 2151-2153.

[26] L. Fabbrizzi, M. Licchelli, L. Mosca, A. Poggi, Coord. Chem. Rev. 2010, $254,1628-1636$. 
[27] (a) C. T. Kresge, M. E. Leonowicz, W. J. Roth, J. C. Vartuli, J. S. Beck, Nature 1992, 359, 710-712; (b) N. K. Mal, M. Fujiwara, Y. Tanaka, Nature 2003, 421, 350-353.

[28] M. Boiocchi, L. Fabbrizzi, M. Garolfi, M. Licchelli, L. Mosca, C.

Zanini, Chem. Eur. J. 2009, 15, 11288-11297.

[29] M. Licchelli, M. Milani, S. Pizzo, A. Poggi, D. Sacchi, M. Boiocchi, Inorg. Chim. Acta 2012, 384, 210-218.

[30] E. P. Barret, L. G. Joyner, P. P. Halenda, J. Am. Chem. Soc. 1951, 73, 373-380.

[31] S. Brunauer, P. H. Emmet, E. Teller, J. Am. Chem. Soc. 1938, 60, 309319.

[32] A. Calvo, P. C. Angelomé, V. M. Sanchez, D. A. Scherlis, F. J. Williams, G. J. A. A. Soler-Illia, Chem. Mater. 2008, 20, 4661-4668.

[33] (a) L. Fabbrizzi, A. Poggi, A. Chem. Soc. Rev. 2013, 42, 1681-1699; (b) A. Bencini, A. M. Bernardo, A. Bianchi, E. García-España, C. Giorgi, S. Luís, F. Pina, B. Valtancoli, Adv. Supramol. Chem. 2002, 8, 79-130; (c) P. Mateus, L. M. P. Lima, R. Delgado, Polyhedron 2013, 52, 25-42; (d) G. Alibrandi, V. Amendola, G. Bergamaschi, L. Fabbrizzi, M. Licchelli, Org Biomol. Chem. 2015, 13, 3510-3524; (e) E. García-España, P. Díaz, J. M. Llinares, A. Bianchi, Coord. Chem. Rev. 2006, 260, 2952-2986.

[34] (a) F. Felix, J. Ferguson, H. U. Guedel, A. Ludi, J. Am. Chem. Soc. 1980, 102, 4096-4102; (b) F. E. Lytle, D. M. Hercules, J. Am. Chem. Soc. 1969, 91, 253-257.
[35] (a) J. Yang, A. Daehler, M. L. Gee, G. W. Stevens, A. J. O'Connor, Studies in Surface Science and Catalysis 2001, 141, 221-228; (b) J. D. Bass, D. Grosso, C. Boissiere, E. Belamie, T. Coradin, C. Sanchez, Chem. Mater. 2007, 19, 4349-4356; (c) X. Huang, N. P. Young, H. E. Townley, Nanomater Nanotechnol. 2014, 4 (doi: 10.5772/58290).

[36] S. El Sayed, M. Milani, M. Licchelli, R. Martínez-Máñez, F. Sancenón, Chem. Eur. J. 2015, 21, 7002-7006.

[37] (a) K. Sasakura, K. Hanaoka, N. Shibuya, Y. Mikami, Y. Kimura, T. Komatsu, T. Ueno, T. Terai, H. Kimura, T. Nagano, J. Am. Chem. Soc. 2011, 133, 18003-18005; (b) L. E. Santos-Figueroa, C. de la Torre, S. El Sayed, F. Sancenón, R. Martínez-Máñez, A. M. Costero, S. Gil, M. Parra, M. Eur. J. Inorg. Chem. 2014, 41-45; (c) M. -Q. Wang, K. Li, J. -T. Hou, M. -Y. Wu, Z. Huang, X. -Q. Yu, J. Org. Chem. 2012, 77, 8350-8354; (d) X. Qu, C. Li, H. Chen, J. Mack, Z. Guo, Z. Shen, Chem. Commun. 2013, 49, 7510-7512; (e) C. Kar, M. D. Adhikari, A. Ramesh, G. Das, Inorg. Chem. 2013, 52, 743 752.

[38] M. Hoffman, A. Rajapakse, X. Shen, K. S. Gates, Chem. Res. Toxicol. 2012, 25, 1609-1615. 
Graphical abstract and text for the Table of contents

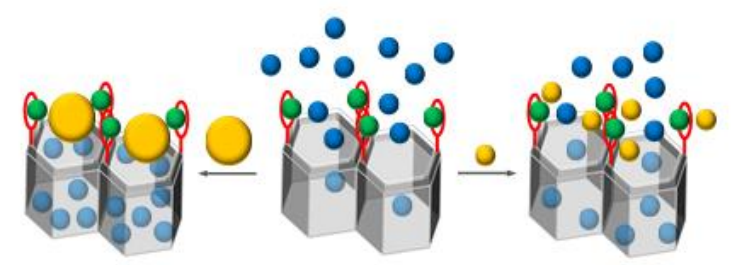

Bulky anions as stoppers: Three hybrid materials based on nano-sized mesoporous silica, loaded with a dye, and functionalized on the external surface with macrocyclic complexes were prepared and characterized. Dye release in water was strongly inhibited by bulky and highly charged anions (e.g. hexamethaphosphate) due to their multiple interactions with metal ions on the surface, while small anionic species were not able to hinder the delivery process. 